\title{
Yield and water use efficiency in 'Tommy Atkins' and 'Palmer' mango trees under localized irrigation with water deficit
}

\section{Produtividade e eficiência de uso da água em mangueiras 'Tommy Atkins' e 'Palmer' sob irrigação localizada com déficit hídrico}

\author{
Marcelo Rocha dos Santos ${ }^{1 *}$; Paulo Roberto Fernandes Cotrim Junior ${ }^{2}$; Naasoom \\ Luiz Santos Mesquita ${ }^{3}$; Sérgio Luiz Rodrigues Donato ${ }^{1}$; Eugênio Ferreira Coelho ${ }^{4}$
}

\section{Highlights:}

The yield of 'Tommy Atkins' mango is higher under micro-sprinkler irrigation than with drip irrigation. RDI with 50 and $75 \%$ ETc in stage III provides similar yields to full irrigation, in 'Tommy Atkins'.

The yield and water use efficiency of 'Palmer' mango trees are higher under drip irrigation.

The strategies of PRD 100, 80 and $60 \%$ and RDI with 50\% ETc in stage III provide greater yields in 'Palmer'.

\begin{abstract}
The increasing water demand of crops in response to climate change; the prospect of expanded irrigated areas; the population growth; and competition with multiple uses of water affect the availability of water resources for agriculture. Thus, measures are required that involve the adoption of irrigationmanagement strategies able to increase water savings without compromising crop yield, especially in semi-arid conditions, where water resources are limited, and in large-scale commercial cultivation such as in 'Tommy Atkins' and 'Palmer' mango, the second most widely grown irrigated fruit crop. The objective of this study was to examine the influence of irrigation systems (drip and micro-sprinkler) and deficit-irrigation strategies on the yield and water use efficiency (WUE) of 'Tommy Atkins' and 'Palmer' mango trees. The study was developed through two experiments conducted in the Irrigated Perimeter of Ceraíma, located in municipality of Guanambi - BA, Brazil. Two trials were carried out in a completely randomized design. For the 'Tommy Atkins' cultivar, 12 strategies were tested, involving regulated deficit irrigation (RDI) by micro-sprinkler irrigation and partial rootzone drying (PRD) by drip, in three production cycles. For 'Palmer' mango, 10 irrigation strategies were evaluated under the same previously described conditions, in only one production cycle. The reduction in water application in RDI was 25 and $50 \%$ of the crop evapotranspiration (ETc); and, in PRD, 20, 40 and $60 \%$ ETc. 'Tommy Atkins' mango achieved higher yields under micro-sprinkler irrigation with full irrigation and in the strategies involving the application of 50 and $75 \%$ ETc in stages II and III. These two strategies also provided greater WUE, along with PRD40. Water use efficiency was lower in the third evaluation cycle when compared with the first. 'Palmer' mango showed higher yields and WUE under drip irrigation, with the best yields achieved with full irrigation and in the strategies of PRD100, 80\%, 60\% and RDI with 50\% ETc in stage III. The best WUE was obtained in PRD with 60 and $40 \%$ ETc.
\end{abstract}

Key words: Irrigation strategies. Drip. Mangifera indica L. Micro-sprinkler. Semi-arid.

\footnotetext{
1 Profs. Drs., Instituto Federal de Educação, Ciência e Tecnologia Baiano, IFBaiano, Campus Guanambi, Guanambi, BA, Brasil. E-mail: marcelo.rocha@ifbaiano.edu.br; sergio.donato@ifbaiano.edu.br

2 M.e em Produção Vegetal no Semiárido, IFBaiano, Campus Guanambi. Guanambi, BA, Brasil. E-mail: paulocotrim31@hotmail. com

3 Discente do Curso de Doutorado do Programa de Pós-Graduação em Fitotecnia, Universidade Estadual do Sudoeste da Bahia, UESB, Vitória da Conquista, BA, Brasil. E-mail: nasonmesquita@yahoo.com

4 PhD em Engenharia de Irrigação, Empresa Brasileira de Pesquisa Agropecuária, EMBRAPA Mandioca e Fruticultura, Cruz das Almas, BA, Brasil. E-mail: eugenio.coelho@embrapa.br

* Author for correspondence
} 


\section{Resumo}

O aumento da demanda hídrica das culturas em função das mudanças climáticas, da perspectiva de expansão da área irrigada, do aumento populacional e da concorrência com os usos múltiplos da água afetam a disponibilidade de recursos hídricos para a agricultura. Isso requer ações que envolvem a adoção de estratégias de manejo irrigação que aumentem a economia hídrica sem comprometer o rendimento da cultura, principalmente em condições semiáridas com maior limitação de recursos hídricos e em cultivo de grande escala comercial, como a mangueira 'Tommy Atkins' e 'Palmer', segunda fruteira mais cultivada sob irrigação. Objetivou-se com este trabalho avaliar a influência dos sistemas de irrigação (gotejamento e microaspersão) e das estratégias de irrigação com déficit na produtividade e na eficiência de uso da água (EUA) em mangueiras 'Tommy Atkins' e 'Palmer'. Os estudos foram desenvolvidos em dois experimentos no Perímetro Irrigado de Ceraíma, município de Guanambi, Bahia. Foram realizados dois ensaios, com delineamento experimental inteiramente casualizados. Com a mangueira 'Tommy Atkins', utilizou-se 12 estratégias de irrigação com déficit controlado (RDI) sob microaspersão e irrigação lateralmente alternada (PRD) sob gotejamento em três ciclos de produção. Com a 'Palmer', foram avaliadas 10 estratégias em de irrigação nas mesmas condições anteriores, em apenas um ciclo de produção. Na RDI a redução na aplicação da água foi de 25 e $50 \%$ da evapotranspiração da cultura (ETc) e na PRD de 20, 40 e 60\% da ETc. A mangueira 'Tommy Atkins' apresentou maior produtividade sob microaspersão, com irrigação plena e nas estratégias com aplicação de 50 e $75 \%$ da ETc nas fases II e III. Estas duas estratégias também propiciaram maior EUA juntamente com a PRD40. A EUA foi menor no terceiro ciclo de avaliação quando comparada ao primeiro. A 'Palmer' apresentou maior produtividade e eficiência de uso da água sob gotejamento, com melhores produtividades sob irrigação plena e nas estratégias PRD100, 80, 60\% e RDI com 50\% da ETc na fase III. A melhor EUA foi obtida na PRD com 60 e $40 \%$.

Palavras-chave: Estratégias de irrigação. Gotejamento. Mangifera indica L. Microaspersão. Semiárido.

\section{Introduction}

Fruit growing stands out in the agricultural scenario of the Brazilian semi-arid region. Within this segment, mango is one of the most widely grown fruit crops, being the second most exported fruit by volume in Brazil in 2018, despite the 5.1\% drop in weight $(10,000 \mathrm{t})$ and the $13.6 \%$ decrease in value, after generating USD 205 million in the previous year (Anuário Brasileiro de Horti \& Fruti, 2019). In Vale do São Francisco, it is estimated that $50 \%$ of the harvested fruit corresponds to the 'Palmer' cultivar; $30 \%$ to 'Tommy Atkins'; and $20 \%$ to 'Keitt', 'Kent', 'Haden', 'Rosa' and other varieties. In 2016, a total of $1,002,189 \mathrm{t}$ were harvested from an area of 61,842 ha in the national territory, constituting an average yield of 16.21 tons per hectare. The northeast region represented the largest harvested area in the country: 44,394 ha (Instituto Brasileiro de Geografia e Estatística [IBGE], 2018) in almost its entirety, in areas affected by low water availability.
The increasing water demand of crops due to the tendency to aridization resulting from climate change due to natural or man-made causes; the population increase; and the modus vivendi of a globalized society that entails greater water consumption and competition with multiple uses of water affect the availability of water resources for agriculture (Cotrim, Santos, Donato, \& Arantes, 2019). The water resource crisis is no longer an exclusive concern of arid or semi-arid regions of the world, and there is a tendency for this situation to worsen if climate-change mitigation actions are not implemented (Clarke et al., 2014). These actions encompass macro-initiatives with global effect and micro-initiatives with local reach, e.g. management strategies for the use of irrigation water to reduce the water demand of crops. Such actions are imperative, given the prospect of a $45 \%$ expansion in the irrigated area in Brazil between 2015 and 2030 (Agência Nacional de Águas [ANA], 2018). This especially critical in semi-arid conditions, 
which mostly have more limited water resources, a greater evapotranspiration demand and are more affected by climate changes.

Thus, in irrigated agriculture centers, notably in the semi-arid region, irrigation management must prioritize rational use so as to increase water use efficiency (WUE) and allow the conservation of water and environmental resources. Water use efficiency can be improved by maintaining or increasing yield with less water supply, which is achieved through the implementation of regulated deficit irrigation (RDI) (Chai et al., 2016) and partial rootzone drying (PRD) strategies (Gotur, Sharma, Joshi, \& Rajan, 2018).

Regulated deficit irrigation is a technique that consists of applying a water deficit in stages when the crop shows less sensitivity. In this way, this reduction in the amount of water used should not cause a decrease in yield beyond the acceptable level to justify the water savings (Chai et al., 2016). Rather, it may maintain or increase yield (Santos, Martinez, Donato, \& Coelho, 2014a, 2014b). The partial rootzone drying technique causes the root system to increase the production of abscisic acid (ABA), which is transported along the vascular axis to the shoots, promoting partial stomatal closure. As a consequence, water loss is reduced and WUE may improve (Romero, Dodd, \& Martinez-Cutillas, 2012) in response to the reduced amount of water applied.

In the mango crop, the RDI and PRD strategies have been investigated (Spreer et al., 2007; Spreer, Ongprasert, Hegele, Wunsche, \& Muller, 2009), Srikasetsarakul et al. (2015); Santos, Donato, Faria, Coelho and Cotrim (2016) and shown results that indicate water and energy savings, improved fruit quality and maintenance of yield.

Information is still lacking on use of localized irrigation and the PRD and RDI strategies in mango in the semi-arid with respect to their potential to maintain yield and increase water use efficiency throughout the cycles so that they can be extrapolated to fruit farmers. On this basis, this study proposes to examine the influence of the drip and microsprinkler irrigation systems and deficient-irrigation strategies on the yield and water use efficiency of mango cultivars 'Tommy Atkins' and 'Palmer'.

\section{Methodology}

Two experiments were carried out for each mango cultivar (Tommy Atkins and Palmer) in commercial plots located in the Irrigated Perimeter of Ceraíma, located in the municipality of Guanambi, southwest Bahia State, Brazil. In this region, the average annual precipitation is $680 \mathrm{~mm}$, with a rainy occurring period between November and March, and average temperature is $25.6^{\circ} \mathrm{C}$. Climatic data (maximum temperature, minimum temperature, average relative humidity, average wind speed and accumulated precipitation) were collected by an automatic meteorological station installed near the experimental area during the evaluation period (Figure 1).

The soil of the experimental areas was classified as a typic Eutrophic Ta FLUVIC NEOSOL with flat to smooth undulating relief and respective sand, silt and clay contents of 600,240 and $160 \mathrm{~g} \mathrm{~kg}^{-1}$ in the $0-0.25 \mathrm{~m}$ layer and 777, 143 and $80 \mathrm{~g} \mathrm{~kg}^{-1}$ in the $0.25-1.00 \mathrm{~m}$ layer. The soil water content with retention of 10 and $1500 \mathrm{kPa}$ was 0.23 and $0.12 \mathrm{~kg}$ $\mathrm{kg}^{-1}$ in the $0.0-0.25$ layer; and 0.15 and $0.07 \mathrm{~kg} \mathrm{~kg}^{-1}$ in the $0.25-1.00 \mathrm{~m}$ layer.

Experimental data were organized to allow an independent evaluation of the drip and micro-sprinkler irrigation systems as well as of the deficit irrigation strategies.

The experimental units were irrigated by a drip system with nine self-compensating emitters per plant on each side, with a unit flow rate of 8 $\mathrm{L} \mathrm{h}^{-1}$; and by micro-sprinklers, using two emitters per plant, with a flow rate of $100 \mathrm{~L} \mathrm{~h}^{-1}$, in the experiments using PRD and RDI, respectively. The drippers in the full-irrigation condition were installed in a ring on the lateral irrigation line within 
a radius of $0.75 \mathrm{~m}$ from the trunk; and, in the PRD installed at $0.30 \mathrm{~m}$ from the trunk. The water used in conditions, longitudinally to the lateral irrigation the irrigation of the experiments came from tubular line, spaced $0.5 \mathrm{~m}$ apart. The micro-sprinklers were wells.

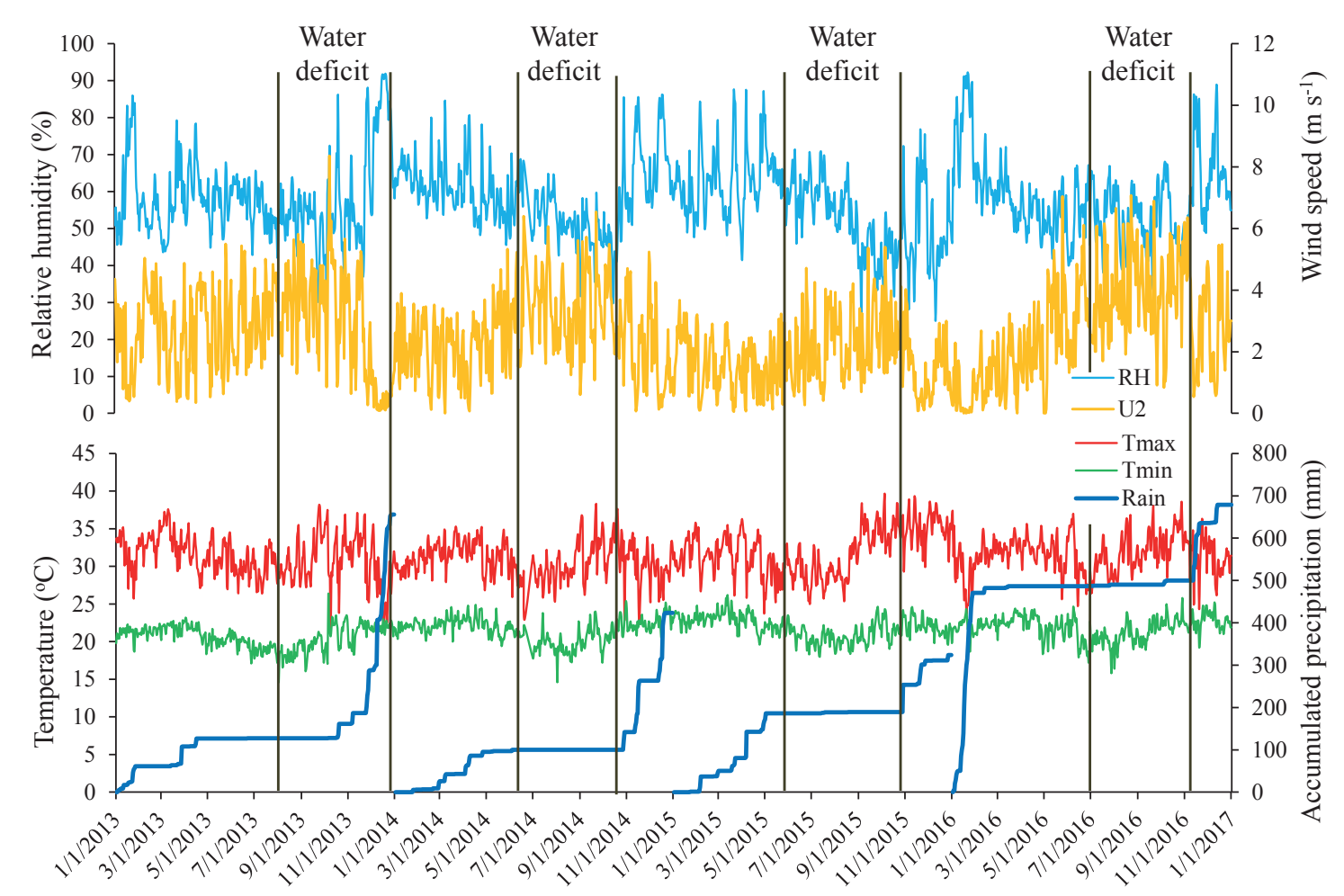

Figure 1. Maximum temperature (Tmax), minimum temperature (Tmin), average relative humidity $(\mathrm{RH})$, average wind speed (U2) and accumulated precipitation (rain) during the evaluated period, 01/01/2013 to $01 / 01 / 2017$. Guanambi, BA.

\section{Trial with 'Tommy Atkins'}

Twelve treatments were tested, consisting of two strategies involving RDI using the micro-sprinkler irrigation system and PRD using the drip-irrigation system. These were applied for three consecutive productive cycles $(2013,2014$ and 2015) in a mango orchard 16 years old at the start of the experiment, with plants spaced $10 \times 8 \mathrm{~m}$ apart. The experiment was laid out in a completely randomized design with a split-plot-in-time arrangement with 12 irrigation strategies $\times 3$ cycles. Irrigation treatments were as follows: FI1 - full irrigation, $100 \% \mathrm{ETc}$ in the conventional micro-sprinkler system, in all stages of fruit development (Stage I - fruit setting; Stage II - fruit expansion; and Stage III - fruit ripening); RDI50S1 - 100\% ETc in stages II and III and 50\%
ETc in stage I; RDI50S2 - 100\% ETc in stages I and III and 50\% ETc in stage II; RDI50S3 - 100\% ETc in stages I and II and 50\% ETc in stage III; RDI75S1 - 100\% ETc in stages II and III and 75\% ETc in stage I; RDI75S2 - 100\% ETc in stages I and III and 75\% ETc in stage II; RDI75S3 - 100\% ETc in stages I and II and 75\% ETc in stage III; FI2 full irrigation, $100 \%$ ETc in the conventional drip system; PRD 100\% ETc; PRD 80\% ETc; PRD 60\% ETc; and PRD 40\% ETc.

To evaluate the influence of the irrigation systems, data referring to full irrigation by microsprinkler and drip were used, which were organized in a $2 \times 3$ factorial arrangement represented by two irrigation systems (drip and micro-sprinkler) and three cycles, in a completely randomized design. 
Each plant irrigated by the same system constituted one replicate, totaling 11 and 13 replicates for the drip and micro-sprinkler systems, respectively.

\section{Trial with 'Palmer'}

In this trial, held in a productive cycle (2016/2017), 10 strategies were tested involving RDI by the micro-sprinkler irrigation system and PRD by the drip-irrigation system. These were applied from flowering to fruit ripening in a sixyear-old orchard with plants spaced $6 \times 5 \mathrm{~m}$.

To evaluate the irrigation strategies, the data were organized in a completely randomized design with 10 treatments, namely, FI1 - full irrigation, $100 \%$ ETc in all stages of fruit development (Stage I, fruit setting; Stage II, fruit expansion; and Stage III, fruit ripening); RDI50S1 - 100\% ETc in stages II and III and $50 \%$ ETc in stage I; RDI50S2 - 100\% ETc in stages I and III and 50\% ETc in stage II; RDI50S3 $-100 \%$ ETc in stages I and II and 50\% ETc in stage III; RDI50S 1, 2 and 3 - irrigation with 50\% ETc in stages I, II and III, under the conventional microsprinkler system; and under the conventional drip system: FI2 - full irrigation, 100\% ETc; PRD 100\% ETc; PRD 80\% ETc; PRD 60\% ETc; and PRD 40\% ETc in the three stages. Four replicates were used with two usable plants per experimental plot.

To evaluate the influence of the irrigation system, data referring to full irrigation in the micro-sprinkler and drip systems were used. The data were organized for two treatments (drip and micro-sprinkler) in a completely randomized design with nine replicates, in which every two plants irrigated by the same system constituted the experimental plot.

\section{Irrigation management}

For both trials, irrigation was performed based on the crop evapotranspiration (ETc), which was obtained as the product of reference evapotranspiration (ETo), the crop coefficient
(Kc) and the landscape coefficient (K1). Reference evapotranspiration was estimated as proposed by Penman-Monteith-FAO56 (Allen, Pereira, Raes, \& Smith, 1998). Solar radiation values were estimated using the Hargreaves equation (Allen et al., 1998), since the weather station did not measure solar radiation.

The Kc values used ranged from 0.45 to 0.87 , as adopted for 'Tommy Atkins' by Cotrim, Coelho, Coelho, Ramos and Cecon (2011) and Santos et al. (2014b). The same Kc of 'Tommy Atkins' was used for 'Palmer', since no crop coefficient for this cultivar has been described in the literature. The landscape coefficient was calculated using the Fereres model, as described by Cotrim et al. (2019), generating a unit value for both cultivars.

Irrigation time per day was obtained using Equation 1. In the event of rain, its amount was subtracted from ETc to obtain the irrigation time. The gross irrigation amounts applied in the trials with mango cultivars 'Tommy Atkins' and 'Palmer' are shown in Tables 1 and 2, respectively.

$$
\mathrm{It}=\frac{\mathrm{ETc} \times \mathrm{Rp} \times \mathrm{S}_{1} \times \mathrm{S}_{2} \times \mathrm{K}_{1}}{\mathrm{n} \times \mathrm{q} \times \mathrm{Ae}}
$$

where,

It is irrigation time, $\mathrm{h} \mathrm{day}^{-1}$;

ETc is crop evapotranspiration, $\mathrm{mm} \mathrm{day}^{-1}$;

$\mathrm{Rp}$ is the replacement of ETc according to the treatment, decimals;

$\mathrm{S}_{1}$ is the spacing between the mango tree rows, $\mathrm{m}$;

$\mathrm{S}_{2}$ is the spacing between plants in the row, $\mathrm{m}$;

$\mathrm{n}$ is the number of micro-sprinklers or drippers per plant;

$\mathrm{Kl}$ is the landscape coefficient, non-dimensional;

$\mathrm{q}$ is the dripper flow, $\mathrm{L} \mathrm{h}^{-1}$; and

Ae is the application efficiency, with an adopted value of $90 \%$. 
Table 1

Gross irrigation amount (GIA) applied in the different treatments and growth cycle of 'Tommy Atkins' mango trees

\begin{tabular}{ccccccc}
\hline \multirow{2}{*}{ Treatment } & \multicolumn{3}{c}{$\%$ ETc } & \multicolumn{3}{c}{ GIA (mm)/Cycle } \\
\cline { 2 - 6 } & SI & SII & SIII & 1 & 2 & 3 \\
\hline FI1 & $100 \%$ & $100 \%$ & $100 \%$ & 428.09 & 460.44 & 539.61 \\
RDI50S1 & $50 \%$ & $100 \%$ & $100 \%$ & 325.06 & 393.22 & 457.77 \\
RDI50S2 & $100 \%$ & $50 \%$ & $100 \%$ & 370.74 & 407.24 & 483.06 \\
RDI50S3 & $100 \%$ & $100 \%$ & $50 \%$ & 374.42 & 350.66 & 408.2 \\
RDI75S1 & $75 \%$ & $100 \%$ & $100 \%$ & 376.58 & 426.83 & 498.69 \\
RDI75S2 & $100 \%$ & $75 \%$ & $100 \%$ & 399.41 & 433.84 & 511.33 \\
RDI75S3 & $100 \%$ & $100 \%$ & $75 \%$ & 401.25 & 405.55 & 473.91 \\
FI2 & $100 \%$ & $100 \%$ & $100 \%$ & 345.73 & 460.44 & 539.61 \\
PRD100 & $100 \%$ & $100 \%$ & $100 \%$ & 345.73 & 460.44 & 539.61 \\
PRD80 & $80 \%$ & $80 \%$ & $80 \%$ & 276.58 & 368.36 & 431.69 \\
PRD60 & $60 \%$ & $60 \%$ & $60 \%$ & 207.44 & 276.27 & 323.77 \\
PRD40 & $40 \%$ & $40 \%$ & $40 \%$ & 138.29 & 184.18 & 215.84 \\
\hline
\end{tabular}

FI1 - full irrigation at all stages of fruit development, 100\% ETc; RDI50S1 - 100\% ETc in stages II and III and 50\% ETc in stage I; RDI50S2 - 100\% ETc in stages I and III and 50\% ETc in stage II; RDI50S3 - 100\% ETc in stages I and II and 50\% ETc in stage III; RDI75S1 - 100\% ETc in stages II and III and 75\% ETc in stage I; RDI75S2 - 100\% ETc in stages I and III and 75\% ETc in stage II; RDI75S3 - 100\% ETc in stages I and II and 75\% ETc in stage III; FI2 - full irrigation, 100\% ETc in the conventional drip system; PRD100 - PRD 100\% ETc; PRD80 - PRD80\% ETc; PRD60 - PRD 60\% ETc; and PRD40 - PRD 40\% ETc.

Table 2

Gross irrigation amount (GIA) applied in the different treatments in 'Palmer' mango trees

\begin{tabular}{ccccc}
\hline \multirow{2}{*}{ Treatment } & \multicolumn{3}{c}{$\%$ ETc } & \multirow{2}{*}{ GIA (mm) } \\
\cline { 2 - 4 } & SI & SII & SIII & 712 \\
FI1 & $100 \%$ & $100 \%$ & $100 \%$ & 613 \\
RDI50S1 & $50 \%$ & $100 \%$ & $100 \%$ & 573 \\
RDI50S2 & $100 \%$ & $50 \%$ & $100 \%$ & 593 \\
RDI50S3 & $100 \%$ & $100 \%$ & $50 \%$ & 356 \\
RDI50S1,2, & $50 \%$ & $50 \%$ & $50 \%$ & 678 \\
FI2 & $100 \%$ & $100 \%$ & $100 \%$ & 678 \\
PRD100 & $100 \%$ & $100 \%$ & $100 \%$ & 542 \\
PRD80 & $80 \%$ & $80 \%$ & $80 \%$ & 406 \\
PRD60 & $60 \%$ & $60 \%$ & $60 \%$ & 271 \\
PRD40 & $40 \%$ & $40 \%$ & $40 \%$ & \\
\hline
\end{tabular}

FI1 - full irrigation at all stages of fruit development, 100\% ETc; RDI50S1 - 100\% ETc in stages II and III and 50\% ETc in stage I; RDI50S2 - 100\% ETc in stages I and III and 50\% ETc in stage II; RDI50S3 - 100\% ETc in stages I and II and 50\% ETc in stage III; RDI50S1, 2, 3 - 50\% ETc in stages I, II and III; FI2 - full irrigation, 100\% ETc in the conventional drip system; PRD100 - PRD 100\% ETc; PRD80 - PRD80\% ETc; PRD60 - PRD 60\% ETc; and PRD40 - PRD 40\% ETc. 
After harvesting, the fruits of both cultivars were weighed and yield results were expressed in $\mathrm{tha}^{-1}$. Subsequently, WUE $\left(\mathrm{kg} \mathrm{ha}^{-1} \mathrm{~mm}^{-1}\right)$ was calculated as the ratio between yield and the gross irrigation amounts (mm) applied in each strategy and in each cycle.

\section{Data analysis}

The yield and WUE data of each trial were subjected to analysis of variance and verification of interaction and effect significance. Because no interaction was detected between the factors, in order to study the factors separately, Tukey's test $(\mathrm{p} \leq 0.05)$ was used to compare the means in the irrigation system and cycle factors and the Scott-

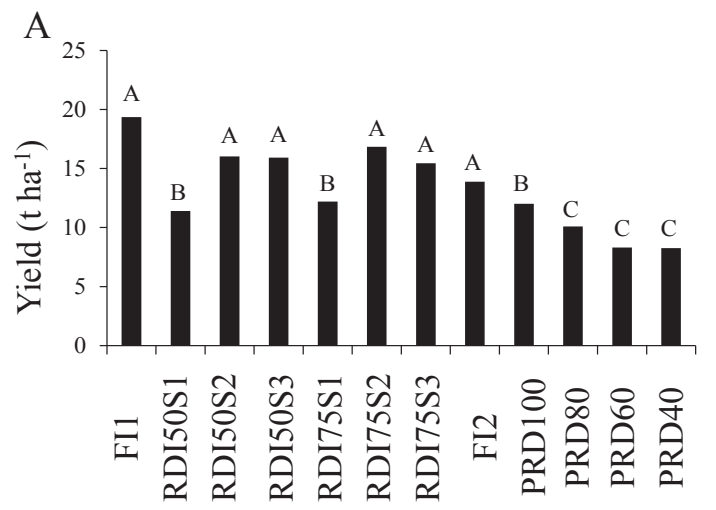

Knott criteria ( $\mathrm{p} \leq 0.05)$ was applied to group the means in the irrigation strategy factor.

\section{Results and Discussion}

Yield and water use efficiency of 'Tommy Atkins' mango

Yield was influenced by the use of different irrigation systems. The average yield of 'Tommy Atkins' mango was higher with the micro-sprinkler system than with drip irrigation (Figure 2A), which provided a $31.11 \%$ lower yield. However, WUE was similar between the irrigation systems due to the lower irrigation amount applied in the drip system, owing to its greater application efficiency (Cotrim et al., 2019) (Figure 2B).

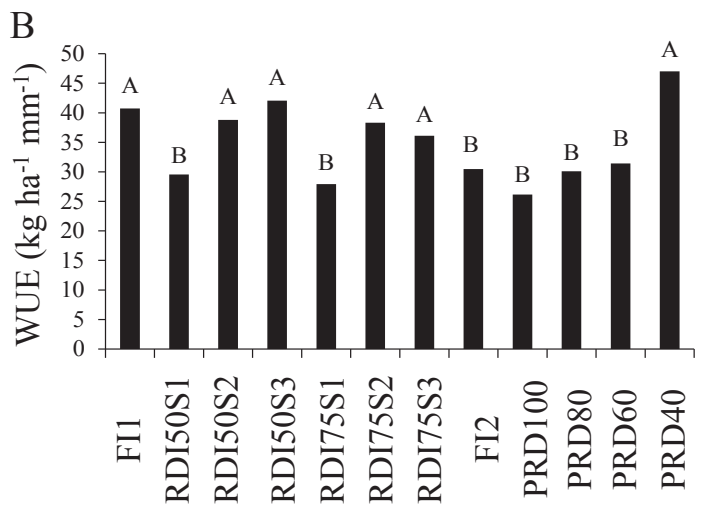

Figure 2. Yield (A) and water use efficiency (WUE) (B) of 'Tommy Atkins' mango trees under microsprinkler and drip irrigation. Guanambi, BA (2013, 2014 and 2015). Means followed by the same letter on the graph bar do not differ at $5 \%$ significance by Tukey's test. The coefficients of variation $(\mathrm{CV}, \%)$ for total yield and WUE were 40.05 and 41.02 , respectively.

According to Coelho, Oliveira, Araújo, Vasconcelos and Lima (2001), the distribution patterns of the roots of irrigated mango trees in semi-arid regions, mainly differ from those found in non-irrigated conditions. This is especially true in drip irrigation, which limits the development of roots, confining them to a volume of soil whose boundary conditions are basically determined by the presence of water in the soil and the soil surface. Additionally, Santos et al. (2014a) evaluated the root distribution of 'Tommy Atkins' mango subjected to micro-sprinkler irrigation and RDI management and found that the highest root density was concentrated at a distance of 0.50 to $1.50 \mathrm{~m}$ from the trunk. 
Therefore, the micro-sprinkler irrigation system is more appropriate, as it irrigates a larger soil surface, reaching a larger area of root concentration.

Despite the constant application of deficit irrigation, yield did not differ significantly across the three evaluated cycles. This result may be associated

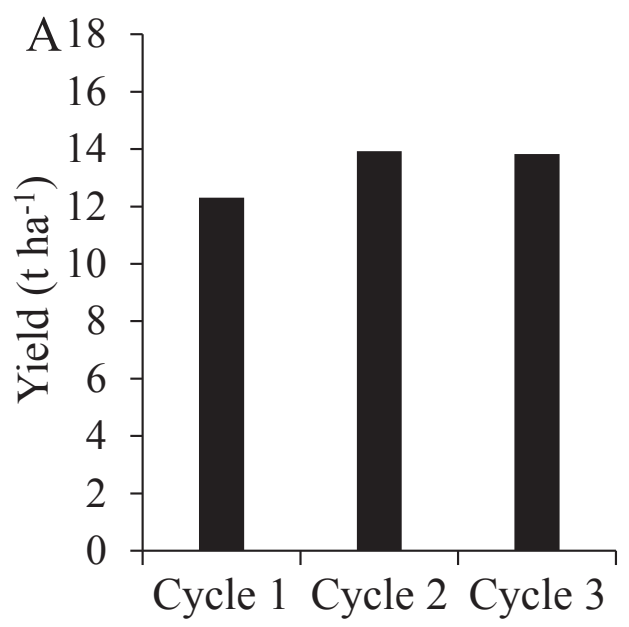

with the age of the orchard, which consisted of well-established plants with a well-developed root system (Figure 3A). However, WUE was influenced by the cycles, with a significantly lower value found in the third cycle as compared with the first. In percentage terms, a $17.65 \%$ reduction was observed (Figure 3B).

Figure 3. Yield (A) and water use efficiency (WUE) (B) of 'Tommy Atkins' mango trees under micro-sprinkler and drip irrigation for three consecutive cycles. Guanambi, BA (2013, 2014 and 2015). Means followed by the same letter on the graph bar do not differ at 5\% significance by Tukey's test. The coefficients of variation (CV, \%) for total yield and WUE were 40.05 and 41.02 , respectively.

Physiologically, WUE describes the intrinsic relationship between carbon fixation and water loss, since water evaporates from the interstitial tissues of the leaves whenever the stomata open for the acquisition of $\mathrm{CO}_{2}$ for photosynthesis (Bramley, Turner, \& Siddique, 2013). Water use efficiency can also be defined as the yield of the crop per unit of water used. Accordingly, its decrease in the last cycle can be explained by the prolongation of this cycle in relation to the first, which results in a greater accumulated final gross irrigation amount without leading to an increase in yield. Another explanation is that the third cycle, which occurred in 2015, was characterized by greater weather stresses in the region (Donato et al., 2019), i.e. less precipitation,

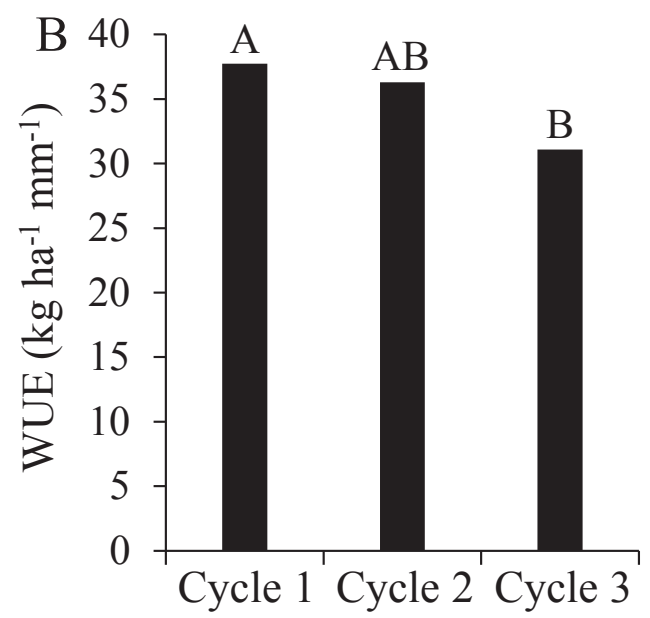

higher temperature, lower relative humidity and higher wind speed (Figure 1). These stresses imply an increase in evapotranspiration demand, which reflected in the higher irrigation amount applied during the cycle and, consequently, the lower WUE.

The strategies involving a reduction in the irrigation amounts in different stages of development (RDI) and partial rootzone drying (PRD) influenced yield and WUE. The cluster composed of the strategies involving PRD80, 60 and $40 \%$ provided the worst yield performances, with significant decreases of the orders of $47.83,57.13$ and $57.39 \%$, respectively, when compared with FI1; and decreases of 27, 29, 40.24 and $40.60 \%$, respectively, as compared with FI2. The cluster 
constituted by the RDI strategy with 50 and $75 \%$ of the crop evapotranspiration in the fruit expansion stage (SII) as well as in the physiological maturity stage (SIII), in addition to FI1 and FI2, provided the highest yield values (Figure 4A). This was possibly because the stage between the end of growth and physiological maturity of the fruits is less sensitive to water deficits as compared with the other stages in which irrigation reduction was applied, making the maturity stage the most suitable for the application of RDI without compromising crop yield (Santos et al., 2014b).
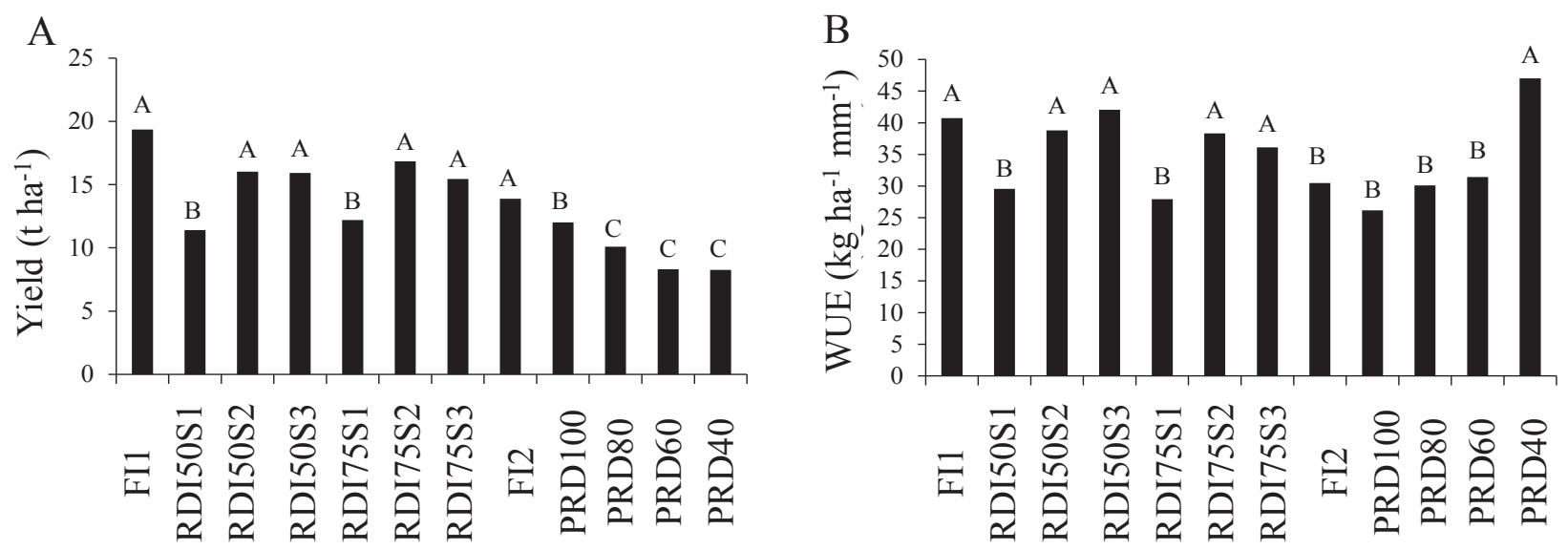

Figure 4. Yield (A) and water use efficiency (WUE) (B) of 'Tommy Atkins' mango trees irrigated by 12 strategies involving regulated deficit irrigation (RDI) and partial rootzone drying (PRD). Guanambi, BA, (2013, 2014 and 2015). FI1 - full irrigation at all stages of fruit development, 100\% ETc; RDI50S1 - 100\% ETc in stages II and III and $50 \%$ ETc in stage I; RDI50S2 - 100\% ETc in stages I and III and 50\% ETc in stage II; RDI50S3 - 100\% ETc in stages I and II and 50\% ETc in stage III; RDI75S1 - 100\% ETc in stages II and III and 75\% ETc in stage I; RDI75S2 - 100\% ETc in stages I and III and 75\% ETc in stage II; RDI75S3 - 100\% ETc in stages I and II and 75\% ETc in stage III; FI2 - full irrigation, 100\% ETc in the conventional drip system; PRD100 - PRD 100\% ETc; PRD80 - PRD80\% ETc; PRD60 - PRD 60\% ETc; and PRD40 - PRD 40\% ETc. Values grouped by the Scott-Knott criteria at 5\% significance.

Water use efficiency was also influenced by the implemented strategies (Figure 4B). The greatest WUE values were observed in RDI with $50 \%$ and $75 \%$ ETc in the fruit development and maturity stages (II and III); in FI1 (full irrigation) in all stages of fruit development, under micro-sprinkling; and in PRD $40 \%$ ETc. The use of RDI with $50 \%$ and $75 \%$ ETc in the flowering stage (RDI50S1 and RDI75S1), in addition to the strategies that included PRD100, 80 and 60, and FI2 (full irrigation, 100\% ETc by drip), provided lower WUE values, which reinforces the idea of greater sensitivity to water deficits during the flowering stage (Santos et al., 2014b) and less adequacy of the PRD strategy for 'Tommy Atkins' mango under the study conditions.

\section{Yield and water use efficiency of 'Palmer' mango}

The yield and WUE of 'Palmer' plants were influenced by the irrigation systems. Drip irrigation provided a significant increase of $21.02 \%$ in average yield, as compared with the micro-sprinkler system (Figure 5A). Water use efficiency was also significantly higher under drip irrigation (32.57\%) (Figure 5B), which was expected, since this variable is calculated as the ratio between yield and the applied gross irrigation amount. Thus, the system that provides greater yield will consequently also provide higher WUE. 

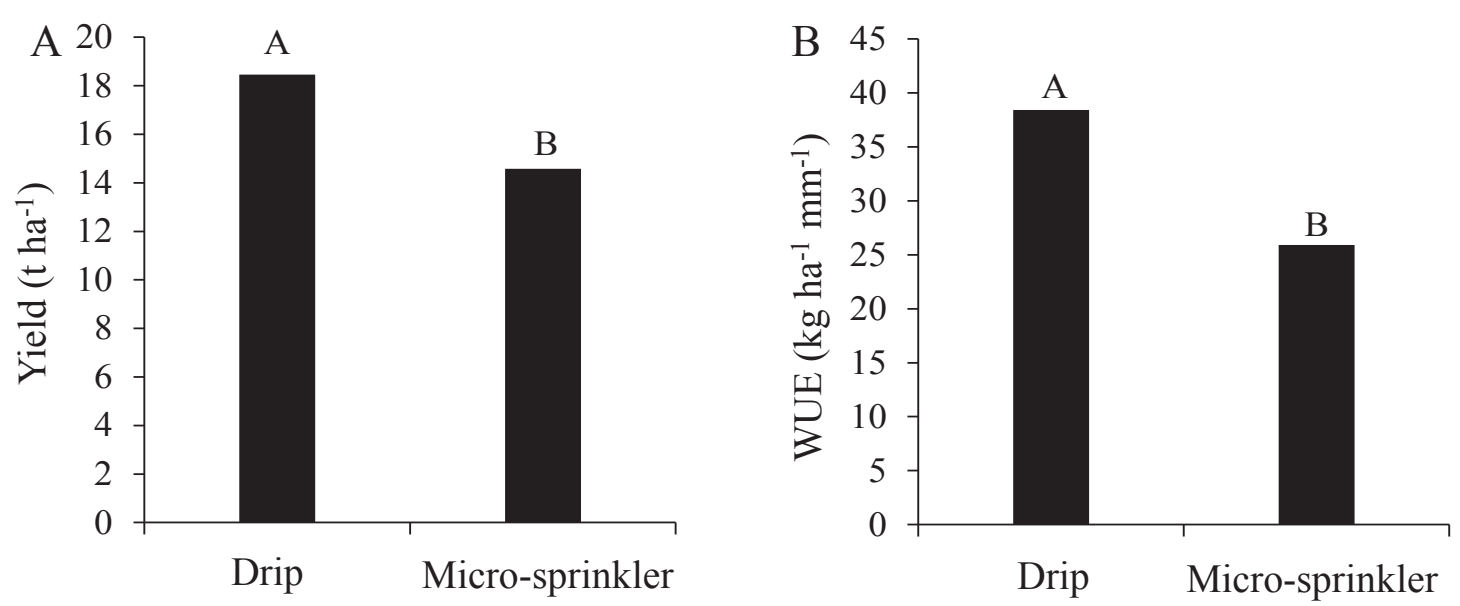

Figure 5. Yield (A) and water use efficiency (WUE) (B) of 'Palmer' mango trees under micro-sprinkler and drip irrigation. Guanambi, BA (2017). Means followed by the same letter on the graph bar do not differ at $5 \%$ significance by Tukey's test. The coefficients of variation $(\mathrm{CV}, \%)$ for total yield and WUE were 30.04 and 29.97 , respectively.

The drip irrigation system adopted prior to the onset of the experiment possibly had an influence on the lateral distribution of the roots, resulting in a greater density of roots near the trunk, since lower availability of water in the soil at greater distances from the trunk reduces root length density (Santos et al., 2014a). This allowed the 'Palmer' mango trees to perform better under drip irrigation, as the water was applied closer to the trunk, coinciding with the area of highest root concentration. Therefore, the definition of the localized irrigation system that provides the greatest yield to mango can be related to specific traits of each cultivar and the distribution of the plant root system.

Different responses were seen in the analysis of yield in 'Palmer' and 'Tommy Atkins' mango under micro-sprinkler and drip irrigation, with 'Palmer' showing higher yields under drip compared with micro-sprinkler irrigation and 'Tommy Atkins' exhibiting the opposite behavior. Cotrim, Coelho, Silva and Santos (2017), on the other hand, found higher yield (37.71 $\left.\mathrm{t} \mathrm{ha}^{-1}\right)$ and WUE (7.49 $\mathrm{kg} \mathrm{ha}^{-1}$ $\left.\mathrm{mm}^{-1}\right)$ in 'Tommy Atkins' with full irrigation than with micro sprinklers $\left(25.45 \mathrm{t} \mathrm{ha}^{-1}\right.$ and $5.05 \mathrm{~kg}$ $\mathrm{ha}^{-1} \mathrm{~mm}^{-1}$ ) (Cotrim et al., 2011), in experiments conducted at the same time and place. However,
Cotrim et al. (2017) worked with drip irrigation, a spacing of $8 \times 4 \mathrm{~m}$ and 312 plants $\mathrm{ha}^{-1}$, whereas Cotrim et al. (2011) used a spacing of $8 \times 8 \mathrm{~m}$ and 156 plants $\mathrm{ha}^{-1}$ in the micro-sprinkler system, suggesting that other factors (e.g. planting density) may influence the diversity of yield results.

In the present study, the fact that two experiments were conducted at different ages, under different managements before treatments were applied, contributed to this result. The 'Tommy Atkins' mango plants, which have a larger aerial architecture, were irrigated by gravity in a furrow and/or basin system, which provided greater lateral root development, and because the micro-sprinkler used in the study had a wetted radius of $2.5 \mathrm{~m}$, the root system likely better re-adapted to the extraction of water and nutrients from the soil, as compared with the drip system, which applies more localized water. On the other hand, in 'Palmer' mango, smaller and younger plants were irrigated by drip, with a root profile pattern already adapted to the system. Thus, the irrigation cycle with micro-sprinklers was not sufficient for the roots to develop throughout the wetted profile, since the irrigation amounts were the same and with a deficit. 
Simões et al. (2018) evaluated the effect of the micro-sprinkler and drip-irrigation systems on the physiological, productive and qualitative traits of fruits of 'Keitt' mango tree at nine years old and found that drip irrigation is the most suitable system for its cultivation, in Vale do Submédio São Francisco, because it interferes positively with photosynthetic activity, stomatal conductance and yield.

The lower WUE in the micro-sprinkler system may be related to the form of water distribution in the soil, since the micro-sprinkler is located far from the plant trunk and part of the soil moistened by the irrigation system is exposed to solar radiation, which can increase evaporation losses and reduce water availability for the plant, as compared with drip irrigation (Simões et al., 2018). In addition, the drip irrigation system allows less evaporation of water from the soil when compared with the micro-sprinkler, especially in regions with strong winds that coincide with the period when irrigation is necessary, as is the case in the evaluated region (Figure 1).

In cultivar 'Palmer', the strategies influenced both yield and WUE (Figure 6). The group composed of treatments with RDI with $50 \%$ ETc in the fruit setting (RDI50S1) and development (RDI50S2) stages, in addition to the $50 \%$ deficit applied to the three stages in the same treatment (RDI50S1, 2 and 3 ), resulted in significant reductions of 27.62, 16.47 and $46.80 \%$, respectively, in the yield of 'Palmer' mango, when compared with the FI1 treatment (full irrigation in all stages of fruit development, 100\% ETc, conventional micro-sprinkler); and reductions of $37.52,27.89$ and $54.08 \%$ when compared with the FI2 treatment (full irrigation, 100\% ETc in the conventional drip system), as well as with PRD40, which was the only one using PRD to exhibit the worst yield.
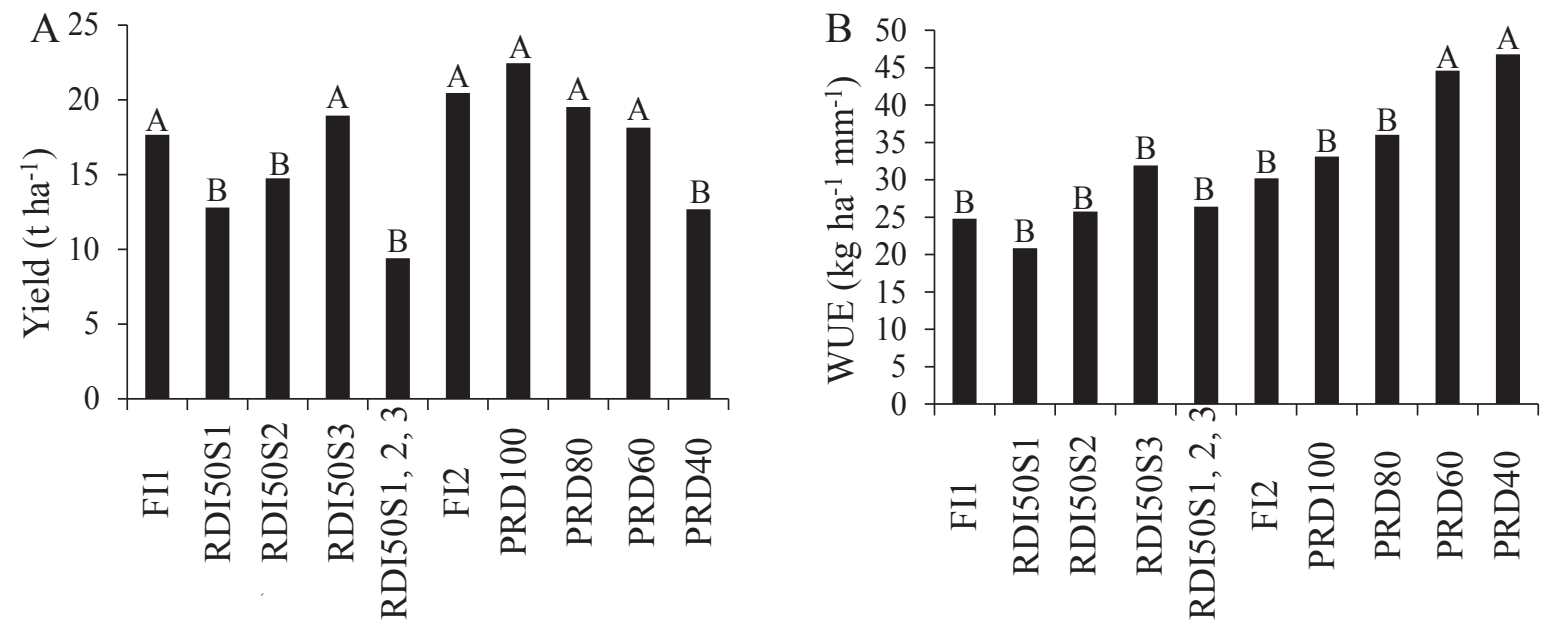

Figure 6. Yield (A) and water use efficiency (WUE) (B) of 'Palmer' mango trees irrigated by 10 strategies involving regulated deficit irrigation (RDI) and partial rootzone drying (PRD). Guanambi, BA, (2017). FI1 full irrigation at all stages of fruit development, 100\% ETc; RDI50S1 - 100\% ETc in stages II and III and 50\% ETc in stage I; RDI50S2 - 100\% ETc in stages I and III and 50\% ETc in stage II; RDI50S3 - 100\% ETc in stages I and II and 50\% ETc in stage III; RDI50S1, 2, 3 - 50\% ETc in stages I, II and III; FI2 - full irrigation, $100 \%$ ETc in the conventional drip system; PRD100 - PRD 100\% ETc; PRD80 - PRD80\% ETc; PRD60 - PRD $60 \%$ ETc; and PRD40 - PRD 40\% ETc. Values were grouped by the Scott-Knott criteria at 5\% significance. 
Along with RDI50S3, the strategies of PRD100, 80 and $60 \%$ provided the best yields, which caused them to be clustered in the same group as treatments FI1 and FI2 (Figure 6A). Therefore, under PRD, 'Palmer' mango trees can be subjected to restrictions of up to $40 \%$ ETc in PRD management and up to $50 \%$ in the RDI management applied during the physiological maturity of fruits, without significant losses in yield.

The cluster composed of treatments PRD40 and PRD60 exhibited the best WUE. The other treatments were clustered in the same group with lower WUE values (Figure 6B).

The higher WUE obtained with PRD60 and PRD40 can be explained by the fact that half of the irrigated rootzone ensures the maintenance of fruit growth, while vegetative growth is reduced (Gotur et al., 2018). However, under PRD40, WUE was preceded by a significant reduction of $38.01 \%$ in yield. Therefore, to improve WUE without affecting yield, PRD60 is recommended.

Plant responses to water stress induced by RDI vary with developmental stages. When deficit is applied to plants in less critical stages, there may be no significant reductions in yield (Chai et al., 2016), as seen in the application of water deficit during the physiological maturity of the fruits of both cultivars.

The better yield performance of the 'Palmer' mango under PRD100, 80 and 60 may be related to the partial drying of the soil, which provides greater control over stomatal opening through chemical signaling via abscisic acid (ABA) (Romero et al., 2012), thereby reducing stomatal conductance and transpiration, maintaining the water potential of the plant and reducing the growth of the aerial part. In this way, nutrients and photoassimilates are targeted for reproductive development. However, more severe deficits compromise the photosynthetic rate (Santos et al., 2016), causing a significant reduction in yield, as observed in the PRD with the application of $40 \%$ ETc.
The application of water deficits at critical stages of the crop or the application of severe deficits compromise yield and may be associated with a decrease in stomatal conductance, which in turn reduced the supply of $\mathrm{CO}_{2}$ to the Rubisco carboxylation sites, negatively affecting the net photosynthesis rate, and, consequently, yield. Zúñiga, Ortega-Farías, Fuentes, Riveros-Burgos and Poblete-Echeverría (2018) found a significant non-linear correlation between net $\mathrm{CO}_{2}$ assimilation and stomatal conductance in 'Carménère' grapes subjected to deficit drip irrigation. Irrigation with $50 \%$ ETc from the fruiting stage until harvest and restricted irrigation from the fruiting stage to maturity with the application of 30\% ETc from maturity to harvest had a significant effect on the yield components, with a reduction in the weight and diameter of the grapes.

Although the best yield and WUE results for 'Palmer' were obtained with the PRD strategy, which translates into environmental and financial gains in terms of water and energy savings, one must consider the complexity of management and the cost of implementing this technique to identify the conditions under which this method would be economically justified (Sadras, 2009). In commercial orchards, financial viability must be taken into account, since the gains in water and energy savings have to be more important than the costs of implementing the systems that enable the use of the PRD strategy, with two mandatory lateral irrigation lines.

\section{Conclusions}

The yield of 'Tommy Atkins' mango is higher under micro-sprinkler irrigation than with drip irrigation.

Regulated deficit irrigation with 50 and $75 \%$ ETc in the fruit expansion and physiological maturity stages provides similar yields to full irrigation and similar WUE to PRD with $40 \%$ ETc. 
Yield and water use efficiency in 'Palmer' mango trees are higher with drip irrigation.

The strategies of partial rootzone drying irrigation with $100,80,60 \%$ ETc and regulated deficit irrigation with $50 \%$ ETc in the stage of physiological maturity provide higher yields in 'Palmer' mango.

Partial rootzone drying with 60 and $40 \%$ ETc provides greater water use efficiency in 'Palmer' mango trees.

\section{Acknowledgments}

Thanks are due to Fapesb and CNPq, which made the development of this study possible through the provision of fellowship grants and financing of materials.

\section{References}

Agência Nacional de Águas (2018). Estudo da ANA aponta em $45 \%$ potencial de expansão da irrigação no Brasil até 2030. Retrieved from http://www3.ana. gov.br/portal/ANA/noticias/estudo-da-ana-apontaem-45-potencial-de-expansao-da-irrigacao-nobrasil-ate-2030

Allen, R. G., Pereira, L. S., Raes, D., \& Smith, M. (1998). (FAO. Irrigation and Dranaige Paper, 56). Crop evapotranspiration: guidelines for computing crop water requirements. Rome: FAO.

Anuário Brasileiro de Horti\&Fruti (2019). Santa Cruz do Sul: Editora Gazeta Santa Cruz. Retrieved from http://www.editoragazeta.com.br/sitewp/wpcontent/uploads/2019/07/HortiFruti_2019_DUPLA. pdf

Bramley, H., Turner, N. C., \& Siddique, K. H. M. (2013). Water use efficiency. In C. Kole (Ed.), Genomics and breeding for climate-resilient crops (vol. 2, pp. 225268). Verlag Berlin Heidelberg: Springer.

Chai, Q., Gan, Y., Zhao, C., Xu, H. L., Waskom, R. M., Niu, Y., \& Siddique, K. H. M(2016). Regulated deficit irrigation for crop production under drought stress. A review. Agronomy for Sustainable Development, 36(3), 1-21. doi: 10.1007/s13593-015-0338-6
Clarke, L., Jiang, K., Akimoto, K., Babiker, M., Blanford, G., Fisher-Vanden, K.,... Vuuren, D. P. van. (2014). Assessing transformation pathways. In O. Edenhofer, R. Pichs-Madruga, Y. Sokona, E. Farahani, S. Kadner, K. Seyboth,,... J. C. Minx (Eds.), Climate change 2014: mitigation of climate change. contribution of working group III to the fifth assessment report of the intergovernmental panel on climate change (pp. 413-510). Cambridge, United Kingdom and New York, NY, USA: Cambridge University Press.

Coelho, E. F., Oliveira, F. C., Araújo, E. C. E., Vasconcelos, L. F. L., \& Lima, D. M. (2001). Distribuição do sistema radicular da mangueira sob irrigação localizada em solo arenoso de tabuleiros costeiros. Revista Brasileira de Fruticultura, 23(2), 250-256. doi: 10.1590/S0100-29452001000200009

Cotrim, C. E., Coelho, E. F., Silva, J. A., \& Santos, M. R. (2017). Irrigação com déficit controlado e produtividade de mangueira 'Tommy Atkins' sob gotejamento. Revista Brasileira de Agricultura Irrigada, 11(8), 2229-2238. doi: 10.7127/rbai. v11n 800728

Cotrim, C. E., Coelho, M. A., Fo., Coelho, E. F., Ramos, M. M., \& Cecon, P. R. (2011). Regulated deficit irrigation and tommy atkins mango orchard productivity under microsprinkling in brazilian semi arid. Engenharia Agrícola, 31(6), 1052-1063. doi: 10.1590/S0100-69162011000600003

Cotrim, C. E., Santos, M. R., Donato, S. L. R., \& Arantes, A. M. (2019). Manejo da irrigação. In D. L. Siqueira, L. C. C. Salomão, \& A. Borém (Orgs.), Manga: do plantio à colheita (pp. 209-235). Viçosa, MG: Editora UFV.

Donato, S. L. R., Arantes, A. M., Gonçalves, N. P., Matos, F. S., Rodrigues, M. G. V., \& Saturnino, H. M. (2019). Aspectos ecofisiológicos, morfológicos, fenológicos e de produção do umbuzeiro e da umbucajazeira. Informe Agropecuário, 40(307), 22-38.

Gotur, M., Sharma, D. K., Joshi, C. J., \& Rajan, R. (2018). Partial root-zone drying technique in fruit crops: a review paper. International Journal of Chemical Studies, 6(2), 900-903, 2018. Recuperado de https://pdfs.semanticscholar.org/6c4e/699b012c26 22a8c0445d15a11f364e7a87c3.pdf

Instituto Brasileiro de Geografia e Estatística (2018). Produção agrícola municipal. Sistema IBGE de recuperação automática - SIDRA. Retrieved from http://http://www.sidra.ibge.gov.br 
Romero, P., Dodd, I. C., \& Martinez-Cutillas, A. (2012). Contrasting physiological effects of partial root zone drying in field-grown grapevine (Vitis vinifera L. cv. Monastrell) according to total soil water availability. Journal of Experimental Botany, 63(11), 1-13. doi: $10.1093 / \mathrm{j} x \mathrm{~b} / \mathrm{ers} 088$

Sadras, V. O. (2009). Does partial root zone drying improve irrigation water productivity in the field? A meta analysis. Irrigation Science, 27(3), 183-190. doi: 10.1007/s00271-008-0141-0

Santos, M. R., Donato, S. L. R., Faria, L. N., Coelho, E. F., \& Cotrim, P. R. F., Jr. (2016). Irrigation strategies with water deficit in Tommy Atkins mango tree. Revista Engenharia Agrícola, 36(1), 1096-1109. doi: 10.1590/1809-4430-eng.agric. v36n6p1096-1109/2016

Santos, M. R., Martinez, M. A., Donato, S. L. R., \& Coelho, E. F. (2014a). Fruit yield and root system distribution of 'Tommy Atkins' mango under different irrigation regimes. Revista Brasileira de Engenharia Agrícola e Ambiental, 18(4), 362-369, 2014a. doi: 10.1590/S1415-43662014000400002

Santos, M. R., Martinez, M. A., Donato, S. L. R., \& Coelho, E. F. (2014b). Tommy Atkins mango yield and photosynthesis under hydric deficit in semiarid region of Bahia. Revista Brasileira de Engenharia Agrícola e Ambiental, 18(9), 899-907. doi: 10.1590/1807-1929/agriambi.v18n09p899-907

Simões, W. L., Ferreira, P. P. B., Mouco, M. A. C., Lima, M. A. C., Guimarães, M. J. M., \& Silva, J. A. B. (2018). Produção e respostas fisiológicas da mangueira cv. Keitt sob diferentes sistemas de irrigação no Submédio do São Francisco. Irriga, 23(1), 34-43. doi: 10.15809/irriga.2018v23n1p34
Spreer, W., Nagle, M., Neidhart, S., Carle, R., Ongprasert, S., \& Muller, J. (2007). Effect of regulated deficit irrigation and partial rootzone drying on the quality of mango fruits (Mangifera indica L., cv. 'Chok Anan'). Agricultural Water Management, 88(1), 173-180. doi: 10.1016/j.agwat.2006.10.012

Spreer, W., Ongprasert, S., Hegele, M., Wunsche, J. N., \& Muller, J. (2009). Yield and fruit development in mango (Mangifera indica L. cv. Chok Anan) under different irrigation regimes. Agricultural Water Management, 96(4), 574-584. doi: 10.1016/j. agwat.2008.09.020

Srikasetsarakul, U., Sringarm, K., Sruamsiri, P., Ongprasert, S., Spreer, W., Schulze, K., \& Müller, J. (2015). Effects of partial rootzone drying irrigation on proline content and yield of mango in a commercial orchard. Acta Horticulturae, 1066(1066), 85-94. doi: 10.17660/ActaHortic.2015.1066.8

Zúñiga, M., Ortega-Farías, S., Fuentes, S., RiverosBurgos, C., \& Poblete-Echeverría, C. (2018). Effects of three irrigation strategies on gas exchange relationships, plant water status, yield components and water productivity on grafted Carménère grapevines. Frontiers in Plant Science, 9(992), 1-13. doi: 10.3389/ fpls.2018.00992 